\title{
ABOUT THE CONTRIBUTORS
}

Marco BÜNTE, Professor, Institute of Political Science, Friedrich-Alexander University, Erlangen Nuremberg, Germany

Niki CHEONG, Lecturer, School of Media and Performing Arts, Coventry University, UK. Formerly Postdoctoral Researcher, Department of Cultural, Media and Visual Studies, University of Nottingham, UK

Pamela COMBINIDO, Independent Researcher, The Philippines

Nicole CURATO, Associate Professor, University of Canberra

Nyi Nyi KYAW, Visiting Fellow, ISEAS - Yusof Ishak Institute, Singapore

Dien LUONG, Visiting Fellow, ISEAS - Yusof Ishak Institute, Singapore

Natalie PANG, Senior Research Fellow, Institute of Policy Studies, Lee Kuan Yew School of Public Policy; and Senior Lecturer, Department of Communications and New Media, National University of Singapore

Muninggar Sri SARASWATI, Deputy Head, Communication Studies Department, Swiss German University, Indonesia

Aim SINPENG, Lecturer, Government and International Relations, University of Sydney, Australia 
Janjira SOMBATPOONSIRI, Assistant Professor, Faculty of Political Science, Thammasat University, Thailand

Ross TAPSELL, Senior Lecturer, College of Asia and the Pacific, The Australian National University

Mun VONG, PhD candidate, School of Government and International Relations, Griffith University, Australia 